\title{
Āq Tappe / Agh Tepe, Tehrān, Mo'āvenat-e pažūhešī, Mīrāte farhangī, Ostān-e Golestān, 1379/2001, 179 p., 11 pl. (résumé en anglais en 4 p. Supp.).
}

\section{Rémy Boucharlat}

\section{(2) OpenEdition}

Journals

Édition électronique

URL : http://journals.openedition.org/abstractairanica/34313

DOI : 10.4000/abstractairanica.34313

ISSN : 1961-960X

Éditeur :

CNRS (UMR 7528 Mondes iraniens et indiens), Éditions de l'IFRI

\section{Édition imprimée}

Date de publication : 15 mai 2003

ISSN : 0240-8910

\section{Référence électronique}

Rémy Boucharlat, «Āq Tappe / Agh Tepe, Tehrān, Mo'āvenat-e pažūhešī, Mīrāț-e farhangī, Ostān-e Golestān, 1379/2001, 179 p., 11 pl. (résumé en anglais en 4 p. Supp.). », Abstracta Iranica [En ligne], Volume 24 | 2003, document 69, mis en ligne le 05 janvier 2010, consulté le 25 septembre 2020. URL : http://journals.openedition.org/abstractairanica/34313; DOI : https://doi.org/10.4000/ abstractairanica.34313

Ce document a été généré automatiquement le 25 septembre 2020.

Tous droits réservés 


\section{$\bar{A} q$ Tappe / Agh Tepe, Tehrān, Mo 'àvenat-e pažūhešì, Mīrātè-e farhangī, Ostān-e Golestān, 1379/2001, 179 p., 11 pl. (résumé en anglais en 4 p. Supp.).}

\section{Rémy Boucharlat}

1 Située à $16 \mathrm{~km}$ de Gonbad-e Kābūs et à proximité de la rivière Gorgān, la colline artificielle de Āq Tappe fait l'objet de fouilles de sauvetage depuis 2000, suite au projet d'aménagement de barrages. Une prospection archéologique couvre la région qui sera ennoyée par le lac artificiel. Le niveau supérieur est de l'Âge du Fer, représenté par 16 tombes du $1^{\text {er }}$ mill. av.n.è; une inhumation de cheval pourrait être associée à l'une d'elles. L'A. signale également quelques tessons de la période achéménide.

2 Souhaitons que l'équipe archéologique dispose du temps nécessaire pour poursuivre l'exploration de ce site témoin de trois périodes très importantes pour l'archéologie de cette région-clé.

\section{INDEX}

Thèmes : 3.2.2. Pré-Achéménides et Achéménides 
AUTEURS

RÉMY BOUCHARLAT

CNRS - Lyon 